v. 7, n. 1

Vitória-ES, Jan - Apr .2010

p. 23-41 ISSN 1808-2386 DOI: http://dx.doi.org/10.15728/bbr.2010.7.1.2

\title{
Problems in measuring capital structure: empiric evidence in Brazil
}

\author{
Márcio André Veras Machado ${ }^{\dagger}$ \\ Paraíba Federal University \\ Otávio Ribeiro de Medeiros $\Omega$ \\ University of Brasília \\ William Eid Júnior ${ }^{¥}$ \\ Getulio Vargas Foundation
}

\begin{abstract}
This empiric-analytic paper, aims at verifying whether the firms' capital structure is sensitive to leverage measures. It also verifies whether most of the leverage variability is due to financial debts. The sample consists of all non-financial companies with data available, positive equity and stocks listed in Bovespa between 1995 and 2007. Accordingly, we sampled on average 133 companies per year. The data required for the analysis were extracted from the Economatica database. In the methodology section we used cross-section linear regression in order to estimate the coefficients and other statistics of interest, following the methodology of Fama and MacBeth (1973). As main results, more than half of the cross-section heterogeneity of the leverage ratio comes from variations on the Non-financial Debts/Total Assets ratio. With respect to the sensibility of the measures used for the leverage, we conclude that profitability is the only variable that is reasonably consistent, in magnitude, sign and significance, with the different measures of leverage.
\end{abstract}

Key-words: Capital structure, leverage, financial debt.

Received in 11/05/2009; revised in 04/04/2010; accept in 04/05/2010

\footnotetext{
Corresponding authors*:

${ }^{*} \mathrm{Ph} . \mathrm{D}$. in Business Administration from the University of Brasília PPGA/UnB.

Professor in the Graduate Business Administration Program of Paraíba Federal University - PPGA/UFPB. Address: Av. Epitácio Pessoa, 3883, Apt. 1602 C - Miramar - João Pessoa - PB - Brazil CEP: 58.032-000. mavmachado@hotmail.com Telephone: (83) 8731-3657
}

${ }^{\Omega} \mathrm{Ph} . \mathrm{D}$. in Economics from the University of Southampton, England. Professor in the Graduate Business Administration Program of University of Brasília - PPGA/UnB. Address: University of Brasília Campus Darcy Ribeiro PPGA Instituto Central de Ciências, ala norte, subsolo, módulo 25 Brasília - DF- Brazil CEP: 70910-900

E-mail: Otavio@unb.br Telephone: (61) 3107.6707.

\footnotetext{
${ }^{¥}$ Post doctorate in Finance from the School of Economics, Administration and Accounting of the University of São Paulo. Professor at FGV/EAESP. Address: Av. Nove de Julho, 2029 - São Paulo - SP - Brazil CEP: 01313-902.

E-mail: william.eid@fgv.br Telephone: (011) 3799-7994.
} 


\section{INTRODUCTION}

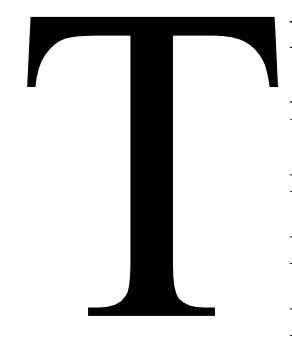

he capital structure is one of the most interesting subjects in finance, nowadays. There are numerous researches related to the matter, both theoretical and empirical (MODIGLIANI; MILLER, 1958; SCOTT, 1972; JENSEN; MECKLING， 1976;

DEANGELO; MANSULIS, 1980; MYERS, 1984; MYERS; MAJLUF, 1984; SHYAM-SUNDER; MYERS, 1999; GOMES; LEAL, 2000; GRAHAM; HARVEY, 2001; BARKER; WURGLER, 2002; FAMA; FRENCH, 2002; DA SILVA; BRITO, 2003; WELCH, 2004; FLANNERY; RAGAN, 2006; WELCH, 2007). The present study starts by asking: how do companies choose their capital structures? This same question was answered by Myers (1984, p.575) as follows:

We do not know (...). We know very little about capital structure. We do not know how firms choose the debt, equity or hybrid securities they issue. We have only recently discovered the capital structure changes convey information to investors.(...) Our theories don't seem to explain actual financing behavior, and it seems presumptuous to advise firm on optimal capital structure when we are so far from explaining actual decisions.

Modigliani and Miller, hereinafter referred to as MM, in their paper "The cost of capital, corporate finance and the theory of investment" (1958), disclosed the grounds to study the effect of the financial structure on the company's value. They had the convincing argument of that the capital structure does not affect the company's value, i.e., there is no better or worse structure for the stockholders. The first test to MM's propositions was based on data from US electrical energy and oil companies. However, the study was based on some hypothesis that were hardly realistic, including: lack of brokerage cost, lack of taxes, lack of bankruptcy costs, riskless debts; absence of agency costs (managers always trying to maximize stockholders' wealth); investors able to take out loans at the same interest rate that corporations; all investors having the same information as managers on the companies' incoming investment opportunities (no information asymmetry); and Earnings before Interests and Taxes (LAJIR, in Portuguese) unaffected by debts.

According to MM (1958), a company's capital weighted average cost cannot be decreased after the replacement of the equity capital with debt, even if the latest is cheaper than the first. This is due to equity capital becoming more hazardous after the addition of debt, and the cost of equity capital ends up increasing. MM (1958) proposed also that the companies' leverage, under certain conditions, would not affect their value, 
i.e., the company should remain with the same average cost of capital, regardless of its structure being of high or low debt. Moreover, they confirmed that the company's equity cost of capital cost grew in line with leverage.

MM's (1958) paper represented the starting point of studies about the companie's capital structure, and subsequent researches were based on their hypothesis, such as Famá, Barros and Silveira's (2001), who made a similar research with the US and Latin American electrical and oil field companies, but with two basic differences: the use of the Capital Asset Pricing Model - CAPM for calculating the companies' capital cost, and the use of best quality statistics.

Regarding the difficult setting of an optimal capital structure, several theories have been developed for identifying the ingredients to the company's capital structure. Jensen and Meckling (1976) defend that the optimal capital structure is defined by taking the agency cost into account. Scott (1972), DeAngelo and Masulis (1980) and Myers (1984), on the other hand, sustain that the optimal capital structure results from a balanced tax benefits and bankruptcy debt-related potential costs. Harris and Raviv (1991) list four main classes of theories about the capital structure determinants, namely: (1) agency theory, (2) asymmetrical information theory, (3) pecking order theory, and (4) corporate control dispute and organizational factors. In addition to the abovementioned, there are recent new approaches to capital structure, such as: the market timing hypothesis (BAKER; WURGLER, 2002) and the managerial inertia approach (WELCH, 2004).

According to Brigham and Houston (1999), there are four main factors influencing the decision-making on capital structure: business risk, or risk degree related to the company's operations, in case it does not have debt: the higher the business risk, the lowest is its indebtness, the tax position of the company: one of the main reasons to use debt lays on the fact that the interest can be deducted for income tax purposes, reducing the actual cost of debt. Another relevant factor relates to the magnitude of the rate, financial flexibility, or the capacity to raise capital under reasonable conditions in an adverse context; the management's conservativeness or boldness: some managers are bolder than others, and, thus, some companies are more inclined to have the debts leveraging earnings.

The capital structure-related studies' main concern is trying to explain the companies' debt changes. The literature is interested in both cross-section explanation, 
since some companies have high debt and others do not, and occasional series, due to the interest in analyzing the capital structure development (WELCH, 2007).

The corporate debt is usually a leverage ratio, which, according to Welch (2007), is a structure raising the sensitivity of the equity capital owners, in respect to the business performance. According to the author, the differences in sensitivity to bankruptcy come immediately from the leverage definition, the tax treatment differences being of secondary relevance.

One of the measures most used in papers on capital structure is the ratio Financial Debt / Total Assets (FD/TA). However, according to Welch (2007), this is a weak proxy of leverage, since the Financial Debt complement in Assets financing is not Equity, but the Non-Financial Debt + Equity.

The idea comes from the concept of inputs source and uses, as well as the equity equality. The Assets (inputs application) are financed by Debt + Equity (inputs source), and all sources have a corresponding application. Nevertheless, Debt is divided into financial and non-financial debt. The financial debt represents that portion that generates the interests' payment, different from the non-financial, which simply results from the company's operating activity. Therefore, by using the FD/TA, its counterpart is the total of Non-Financial Debt + Equity ((NFL+E)/TA) (WELCH, 2007).

One way to solve the issue would be to use Total Debts / Total Assets (TD/TA) ratio or the Financial Debts / Capital Invested (FD/CI) ratio, which is, in turn, represented by Total Assets - Non-Financial Debt. According to Welch (2007), using the FD/TA ratio as leverage would not cause any problems in the event the NFD/TA ratio being insignificant.

Thus, the analysis is focused on finding whether the greatest part of the levering variation is really due to the ratio used in the capital structure literature (FD/TA), or results from the Non-Financial Debt, leading to loss of statistic and economic relevance. This way, this paper contributes to the state-of-art, as it indicates the adequate leverage proxy to measure capital structure to future research.

In the light of the foregoing, there are the following questions: is the capital structure sensible to the measures used to the proxy leverage?

Based on the issue presented, the following hypotheses are raised:

H1: Most part of the leverage variability is due to the Financial Debt variability;

$\mathrm{H} 2$ : Capital structure is sensible to the leverage measures. 
Thus, this paper aims at checking, under the methodology used by Welch (2007), if capital structure is sensible to the measures of leverage. the paper has five other sections. The following presents the theoretical references, addressing the capital structure. The third section describes the methodology applied. The fourth shows the research results. In addition, the fifth features the conclusion. Finally, the references come in the end.

\section{LITERATURE REVIEW}

\subsection{Capital Structure Theories}

The main theories of capital structure are: trade-off, agency theory, pecking order, market timing and managerial inertia, as discussed below. Trade-off theory presumes that the companies have an optimal debt ratio, maximizing the company's value, minimizing the prevailing market fail costs, such as taxes, bankruptcy costs and agency costs (KJELLMAN; HANSEN, 1995).

The trade-off hypothesis considers the company's debt as an analysis to the costs and benefits provided by loans. The company is depicted as balancing the tax benefit and the financial risk. The company is supposed to replace third parties' capital with own capital or vice-versa, to the maximization of the company's value. Moreover, the company's value is maximized when the marginal tax benefits provided by the use of third parties' capital are equal to the marginal cost related to the probability of bankruptcy from using debt.

Unfortunately, there is no formula providing the accurate determination of a company's optimal debt level to the moment. In practice, several managers work in a subjective perspective. They usually try to operate in a range approximating them to what they believe to be the optimal capital structure. According to Ross, Westerfield and Jaffe (2001), this is due to the difficulty of expressing bankrupt costs accurately.

Considering that this static model of the trade-off theory is based on the lack of transaction costs and its non-variability throughout time, authors like Fama and French (2002), Shyam-Sunder and Myers (1999) and Flannery and Rangan (2006) developed trade-off dynamic models, which, basically, seek an optimal capital structure ranging throughout time, with the adjustments required, in order to have the best cost-benefit capital structure. The agency theory focuses on the relations resulting from tasks that, due to its complexity or costs, cannot be performed by only one person, named 
principal. The principal is obliged to hire an agent with specific skills or qualification to perform such task (JENSEN; MECKLING, 1976).

Jensen and Meckling (1976) define the agency relation as a contract by which a person hires the services of a third party to perform, in behalf and at the expenses of the person, a certain task. The authors state that, in case both parties are utility maximizers, there are good reasons to believe that the agent, sometimes, will not act to the best interests of the principal. The agency theory is based on two essential problems: moral hazard and adverse selection. Moral hazard is grounded on the possibility of the agent using the information in its own benefit and, occasionally, against the principal. The adverse selection issue is a consequence of the information asymmetry, as the agent has supplementary information in its decision-making process, ignored by the principal. Moreover, the principal is not able to assess if the agent's performance is the most adequate to maximize its utility (JENSEN; MECKLING, 1976). Jensen and Meckling (1976) identified two types of interest conflicts: conflicts between stockholders and managers, and the conflict between creditors and stockholders. The conflicts between stockholders and managers take place as the managers have less than $100 \%$ of the company's stock, and, hence, they cannot take the total earnings resulting from the adding-value activities.

On the other hand, they have the burden of such activities, as their efforts are the company's propeller. The conflict between stockholders and creditors takes place because the debt contract provides controllers an incentive to influencing investments. These conflicts, resulting from the use of debt, make stockholders' to adopt protectionist strategies. Interest conflicts are not only between stockholders and managers and stockholders and creditors, but also between the several groups of stockholders, making the analysis a very complex task. The pecking order theory is due to Myers (1984) and Myers and Majluf (1984). According to them, the companies prefer internal to external financing, and, in case the external financing is required, the company will issue risk-free securities first, i.e., the companies start with debts, likely hybrid securities, such as convertible, or, maybe, the equity capital as last option.

In the pecking order theory, a company does not have a well-defined capital structure. According to Kjellman and Hansen (1995), there are two ways of explaining this theory. The traditional vision states that the theory may be met, considering the high costs of transaction, taxes and agency costs. The other explanation, by Myers and Majluf (1984), is that the theory is related to the information asymmetry, stating that the 
people in the company have more information than those out of it. Myers and Majluf (1984) have shown that if investors and creditors are less informed than the company's managers on the value of their assets and their future expectations, than debts and stocks can be mispriced by the market.

However, the theory suggests that, although investors fear the wrong valuation of debt and stock prices, the fear is greater regarding stocks. Thus, upon external financing requirement, debt should be issued before stocks. Stocks should be issued only after the company reaches its maximum debt capacity. Myers and Majluf (1984) evidenced that the undervaluation may be such that raising capital to finance new investment project leads the new stockholders to get wealth superior to the net present value raised by the new project, resulting in a loss to the current stockholders, causing them to reject the project, even if it has a positive present value.

According to Myers and Majluf (1984), sub-investment, resulting from the rejection of a project with positive present value, can be avoided if the companies finance their projects with retained earnings first, then with debt and, finally, with the issuance of new stock, which should be the last source used. On the other hand, if the company is overvalued by the market, it should issue stocks, signaling this valuation to investors.Market timing, as per Baker and Wurgler (2002), refers to the practice of issuing stocks when prices are high, and rebuying them when the price falls, intending to explore the provisional fluctuation of the share price related to other capital forms.

Differently from the trade-off and pecking order theory approaches, in which the financing sources choice is set by internal issues, the market timing theory is focused on the external conditions of stock and debt markets. According to this theory, the companies would benefit from the issuance of debt or stocks in favorable markets, and take these securities out of the market in unfavorable conditions (BAKER; WURGLER, 2002). Therefore, according to the market timing theory, the companies' capital structure is formed under the result accrued from their attempt to find out the timing to their stocks and debt market, fostering the arising of two important theoretical relations:

- Low-debt companies would be those issuing stocks when they were highly valuated (higher rate between market value and accounting value of financing sources); 
- High-debt companies would be those issuing stocks when they were under valuated (low quotient between market value and accounting value of financing sources).

Evidence in favor of the market timing has already been found in Graham and Harvey (2001), in which two thirds of the accounting-financial managers states that their actions being low- or high- valuated affects their decision-making upon the issuance of stocks. Several factors may cause deviations from the optimal structure, including the company stock performance. Ceteris paribus, the company should raise value during a given period, the market value debt degree decreases, and vice-versa. In respect to this aspect, Welch (2004) investigated whether the current capital structure is adjusted by the debt of the previous period or the capital structure fluctuates with the stock price, in an attempt to identify whether the companies adjust their capital structure under the good or bad stock performance.

Welch (2004) used, for this purpose, data from American companies in the period between 1962 and 2000, assessing the impact of the stock performance in the following ten years. In all regressions, the implicit debt (ranging only due to the stock return) was most relevant than the debt of $k$ previous periods in the determination of the debt in $t+k$. Such evidence provides strong support to the idea that the companies fail to adjust their capital structure towards an optimal level, even when a longer term of ten years is considered, in opposition to the concept of optimal structure of the static tradeoff models.

Among the other main facts mentioned by Welch (2004), we emphasize: in opposition to the theories on the matter, the companies issue stocks and debt very often, and have their capital structure more influenced by stock returns, rather than by pursuing a capital target structure.

The companies seem to be very active, in particular, as far debt management is concerned; and the adjustment of the debt level under the variations on the stock price is not their only purpose.

\section{METHODOLOGY}

\subsection{Research Characterization}

Regarding the research characterization, a empiric-analytical study was chosen, which, according to Martins (2002, p. 34), 
[...] are approaches presenting the use of techniques of remarkably quantitative data collection, treatment and analysis [...]. They have a strong concern about the causal relationship between variables. The validation of the scientific proof is achieved by testing the instruments, relevance and systematization degrees of the operational definitions.

\subsection{Sample}

The sample includes all non-financial companies with stocks listed in the Stock Exchange of the State of São Paulo (BOVESPA) between 1995 and 2007, a period of greater money stability, after 1994. The data required for analysis were extracted from Economatica's database.

The study did not include the companies classified as financial institutions and insurance companies aswell as investment funds, besides those companies with missing data, and those with negative Equity, which would distort the analysis, considering that several measures were expressed as a percentage of such value. Thus, the debt variables FD/TA, NFD/TA and TD/TA and the E/TA ratio result in values between zero and one. The companies with missing data on the previous year were also not included, due to the use of dynamic models, with regressions having variables in the first differences. Table 1 shows the research sample.

Table 1 - Sample

\begin{tabular}{l|l|ll|l|l}
\hline Period & First Sample & $\begin{array}{l}\text { Negative } \\
\text { Companies }\end{array}$ & $\begin{array}{l}\text { Equity } \\
\text { the previous year }\end{array}$ & $\begin{array}{l}\text { Final } \\
\text { Sample }\end{array}$ \\
\hline 1996 & 130 & 4 & 20 & 106 \\
1997 & 129 & 4 & 18 & 107 \\
1998 & 135 & 5 & 27 & 103 \\
1999 & 183 & 13 & 48 & 122 \\
2000 & 175 & 9 & 18 & 148 \\
2001 & 181 & 16 & 17 & 148 \\
2002 & 172 & 14 & 14 & 144 \\
2003 & 194 & 24 & 27 & 143 \\
2004 & 209 & 30 & 24 & 155 \\
2005 & 208 & 24 & 20 & 164 \\
2006 & 234 & 29 & 36 & 169 \\
2007 & 109 & - & 17 & 92 \\
\hline S00 & & & & \\
\hline
\end{tabular}

Source: Elaborate by the authors

\subsection{Model Description}

The model followed the methodology used by Welch (2007). Although other debt measures are common, the most used is that dividing financial debt by total assets, i.e., (FD/TA), the assets being measured usually at accounting value, or, sometimes, market value, by replacing the Equity's accounting value with its market value. 
The increase in the said (FD/TA) ratio is expected to raise the leverage, as well as to cause a decrease to the equity divided by total assets (E/TA) ratio. However, debts are composed by a financial part and a non-financial part.

Therefore, according to Welch (2007), this is a misinterpretation, as the opposite of the financial debt is not equity, but the sum of the non-financial part and the equity, as per Equation 1:

TotalAsset $s=$ Financiald ebt + Non - financiald ebt + Equity

On the other hand, the opposite of the FD/TA ratio is not E/TA, but Equity + Non-Financial Debt / Total Assets (SE + NFD)/TA. The real debt measure should be, as per Welch (2007), the Total Debts / Total Assets (TD/TA), or the Financial Debt / Capital Invested (FD/CI), represented by the Total Assets - Non-financial Debt. According to the author, ratio FD/TA would be fit only if the NFD/TA ratio were irrelevant.

In order to test whether the companies with higher ratio FD/TA can be seen as more leveraged, the linear cross-section regression was applied, as per Equations 2 and 3:

$$
\begin{aligned}
& \frac{\mathrm{E}}{\mathrm{TA}}=\alpha_{0}+\alpha_{1}\left(\frac{\mathrm{FD}}{\mathrm{TA}}\right)+\varepsilon \\
& \frac{\Delta_{\frac{\mathrm{E}}{\mathrm{TA}}}}{\mathrm{TA}}=\alpha_{0}+\alpha_{1}\left(\Delta \frac{\mathrm{FD}}{\mathrm{TA}}\right)+\varepsilon
\end{aligned}
$$

Where:

$$
\begin{aligned}
& \frac{\mathrm{E}}{\mathrm{TA}}=\text { Dependent variable, represented by the Equity / Total Assets; } \\
& \alpha_{0}=\text { Intercept; } \\
& \alpha_{1}=\text { Inclination coefficient; } \\
& \frac{\mathrm{E}}{\mathrm{TA}}=\text { Independent variable, represented by the Financial Debt / Total Assets; } \\
& \varepsilon=\text { Error term. }
\end{aligned}
$$

As in Welch (2007), those regressions were used with the purpose of relating a debt measure commonly used (variable regardless of the model) to the real ratio.

This model is intended to check the percentage of the cross-section heterogeneity due to the real leverage ratio (one minus the variable, depending on the model).Equations 2 and 3 are to be interpreted based on their $\mathrm{R}^{2 \text { ' }}$ s. 
Since it is standardized between zero and one, by subtracting the $\mathrm{R}^{2}$ from one, the result is the explanation percentage due to the non-financial debt. Therefore, the higher the $\mathrm{R}^{2}$, the lower is the non-financial debt impact on the real leverage index. Accordingly, the higher the $\mathrm{R}^{2}$, the lower is the non-financial debt impact on the real leverage index.

Thus, a low explanatory power to the model indicates that any regression in these companies by using the (FD/TA) ratio may suffer from a definition error, rather than on an error in the use of the variable.

The companies with high FD/TA ratio cannot be compared to highly leveraged companies, due to the non-financial component of Debt, as per the introduction.After that, the impact on the cross-section regression was identified by using three leverage measures and one control measure as dependent variables and the following independent variables: Log os Assets accounting value (LogAT), market-to-book ratio (MB), represented by the market value divided by the Equity accounting value , the Net Profit / Total Assets ratio (NP/TA) and the assets tangibility ratio, represented by Inventory + Fixed Assets / Total Assets ((Inventory+FIX)/TA). Therefore, the Equation 4 is:

$$
y_{i}=\alpha_{0}+\alpha_{1}(\log A T)+\alpha_{2}(M B)+\alpha_{3}\left(\frac{N E}{T A}\right)+\alpha_{4}\left(\frac{\text { Inventories }+F I X}{T A}\right)+\varepsilon
$$

Where $y_{i}$ represents the four dependent variables used, namely: Financial Debt / Total Assets (FD/TA), Financial Debt / Capital Invested (FD/CI), Total Debts / Total Assets (TD/TA) and, for comparison purposes, one part of the Total Assets (1/TA) and $\varepsilon \quad$ being the error term. The choice of variables was made under the results comparability. Thus, the same variables in Welch (2007) applied. However, other variables might be used as capital structure explanatory factors, but the purpose of Equation 4 is analyzing whether the definition of leverage distorts the regression results, regarding both magnitude and change in sign.

Equations 2, 3, and 4 were subject to linear regression by OLS, in order to estimate the coefficients and the other interest statistics, according to Fama and MacBeth (1973) methodology. Fama and McBeth (1973) suggest an alternative to the estimate of regressions in cross-section, as well as to the calculation of standard deviations and test statistics. 
This process is highly used in studies in the corporate finance area, being historically viewed as an important procedure, easily implemented (DA SILVA; BRITO, 2003). Fama and Macbeth (1973) procedure is summarized in three phases. The first estimates the cross-section regressions for each period, as per Equation 5:

$$
\mathrm{y}_{i t}=\alpha_{\mathrm{t}}+\beta_{\mathrm{t}} \mathrm{x}_{i t}+\varepsilon_{i t}
$$

Where, $\varepsilon_{i t}$ is the error term for each $\mathrm{t}=1,2, \ldots, \mathrm{n}$;

$\mathrm{y}_{i t}=$ variable dependent on regression, of the company $i$ in the period $t$;

$\alpha_{\mathrm{t}}=$ intercept;

$\beta_{\mathrm{t}}=$ inclination coefficient;

$\mathrm{X}_{i t}=$ variable independent on regression, of the company $i$ in the period $t$;

After that, the averages and variances of the coefficients achieved in each regression estimated by Equation 5, as per Equations 6 to 9:

$$
\begin{aligned}
& \bar{\alpha}=\sum^{n} \hat{\alpha} t^{\underline{t}} \\
& \bar{\beta}=\sum_{t=1}^{n} \hat{\beta}_{t} \\
& \sigma(\hat{\alpha})=\sum_{n} \frac{(\alpha-\alpha)}{-_{t}} \\
& \sigma(\beta)=\sum_{n}^{t=1} \underbrace{\left(\beta \underline{t}^{2} \beta\right)}_{t} \\
& t=1 \quad t^{2}
\end{aligned}
$$

Finally, the definition to the statistic of test $t$ of Student, intended to test the results relevance, as per Equations 10 and 11:

$$
\begin{aligned}
& t_{\alpha}=\frac{\bar{\alpha}}{\frac{\sigma(\alpha)}{\sqrt{n}}} \\
& t_{\beta}=\frac{\beta}{\frac{\sigma(\alpha)}{\sqrt{n}}}
\end{aligned}
$$

According to Fama and French (2002), one of the most serious problems in empirical studies about leverage is standard error bias, which may distort the results.

Yet according to the authors, the studies make use of regressions with crosssection and panel data. However, when cross-section regressions are used, the interference problem due to the correlation of resisual has been ignored. 
The studies using panel regressions ignore both the residuals autocorrelation and the standard error coefficient estimates.Cochrane (apud Brito and Lima, 2005) states that when the dependent variable of Equation 5 is not fluctuating in time, Fama and McBeth (1973) procedure is numerically equivalent to the estimate by panel and plain cross-section with correction for autocorrelation.

However, upon time variation in the dependent variable, there are significant differences between these estimation methods, where the result from Fama and McBeth (1973) procedure is the most reliable.

According to Brito and Lima (2005), the main advantage of Fama and McBeth (1973) estimate is correcting the data for a sectional correlation, delivering the best results with a relevant reduction in the average deviations.

Besides such correction, this procedure is reliable concerning the heteroscedasticity, as there is no correction for data heteroscedasticity for an average sample (FAMA; FRENCH, 2002).

The autocorrelation issue, in turn, is solved by adjusting the test statistic required. Fama and French (2002) suggest that, in case of significant first order autocorrelation, adjusted critical values shall apply, by multiplying them by two. The data analysis applied the statistic packages SPSS 15.0 and Eviews 5.0.

\section{RESULTS}

Table 2 shows the descriptive statistic of the variables FD/TA, NFD/TA and E/TA. Non-financial debt represents, in average, $24.90 \%$ of total assets, while the financial debt presented an average of $18.69 \%$ and Equity, $56.41 \%$.

Table 2 - Ratios FD/TA, NFD/TA and E/TA Average and Deviations to Accounting values (\%)

\begin{tabular}{|c|c|c|c|c|c|c|c|}
\hline \multirow{2}{*}{ Year } & \multicolumn{2}{|c|}{ FD/TA } & \multicolumn{2}{|c|}{ NFD/TA } & \multicolumn{2}{|l|}{$\mathrm{E} / \mathrm{TA}$} & \multirow{2}{*}{$\mathrm{N}$} \\
\hline & Avg. & Standard Deviation & Avg. & Standard Deviation & Avg. & Standard Deviation & \\
\hline 1996 & 17,24 & 15,05 & 21,94 & 15,95 & 60,82 & 23,04 & 106 \\
\hline 1997 & 18,99 & 15,07 & 22,81 & 15,97 & 58,19 & 22,85 & 107 \\
\hline 1998 & 19,42 & 16,22 & 23,79 & 16,93 & 56,79 & 23,00 & 103 \\
\hline 1999 & 18,61 & 16,47 & 22,70 & 18,27 & 58,69 & 25,44 & 122 \\
\hline 2000 & 19,15 & 17,86 & 24,35 & 18,14 & 56,49 & 24,89 & 148 \\
\hline 2001 & 19,82 & 18,49 & 26,26 & 18,31 & 53,92 & 25,02 & 148 \\
\hline 2002 & 21,78 & 19,94 & 28,04 & 18,94 & 50,17 & 26,57 & 144 \\
\hline 2003 & 19,79 & 18,59 & 26,37 & 18,42 & 53,84 & 26,07 & 143 \\
\hline 2004 & 18,10 & 17,31 & 28,32 & 18,49 & 53,58 & 25,66 & 155 \\
\hline 2005 & 17,69 & 16,59 & 27,68 & 19,26 & 54,63 & 25,35 & 164 \\
\hline 2006 & 16,78 & 15,40 & 24,27 & 17,12 & 58,95 & 24,17 & 169 \\
\hline 2007 & 16,85 & 14,89 & 22,32 & 13,14 & 60,83 & 21,06 & 92 \\
\hline General Avg. & 18,69 & 16,82 & 24,90 & 17,41 & 56,41 & 24,43 & 133 \\
\hline
\end{tabular}

Source: Elaborate by the authors 
Table 3 presents the results, using market values, namely: $17.64 \%, 24.63 \%$ and $57.73 \%$, to FD/TA, NFD/TA and E/TA, respectively. The non-financial debt is relevant, with both accounting (Table 2) and market (Table 3) values. There is no variation trend on the indicators over the period analyzed.

Table 3 - Ratios FD/TA, NFD/TA and E/TA Average and Deviations to Market values (\%)

\begin{tabular}{|c|c|c|c|c|c|c|c|}
\hline \multirow[b]{2}{*}{ Year } & \multicolumn{2}{|c|}{ FD/TA } & \multicolumn{2}{|c|}{ NFD/TA } & \multicolumn{2}{|l|}{ E/TA } & \multirow[b]{2}{*}{$\mathrm{N}$} \\
\hline & Avg. & Standard Deviation & Avg. & Standard Deviation & Avg. & $\begin{array}{l}\text { Standard } \\
\text { Deviation }\end{array}$ & \\
\hline 1996 & 20,92 & 18,59 & 27,48 & 20,12 & 51,60 & 27,89 & 106 \\
\hline 1997 & 22,39 & 18,57 & 27,95 & 20,00 & 49,66 & 28,82 & 107 \\
\hline 1998 & 26,13 & 21,42 & 31,62 & 21,50 & 42,25 & 27,61 & 103 \\
\hline 1999 & 18,50 & 17,79 & 23,89 & 20,14 & 57,62 & 27,89 & 122 \\
\hline 2000 & 18,94 & 18,00 & 26,64 & 21,07 & 54,42 & 28,22 & 148 \\
\hline 2001 & 19,95 & 18,81 & 29,36 & 22,38 & 50,69 & 29,25 & 148 \\
\hline 2002 & 21,73 & 20,49 & 31,63 & 24,13 & 46,64 & 30,39 & 144 \\
\hline 2003 & 17,07 & 17,89 & 24,31 & 20,78 & 58,62 & 28,75 & 143 \\
\hline 2004 & 14,16 & 15,96 & 23,49 & 21,06 & 62,35 & 28,63 & 155 \\
\hline 2005 & 13,68 & 15,57 & 23,22 & 21,70 & 63,09 & 28,66 & 164 \\
\hline 2006 & 10,56 & 12,09 & 16,20 & 16,56 & 73,24 & 23,28 & 169 \\
\hline 2007 & 7,63 & 8,09 & 9,78 & 8,15 & 82,59 & 13,70 & 92 \\
\hline General Avg. & 17,64 & 16,94 & 24,63 & 19,80 & 57,73 & 26,92 & 133 \\
\hline
\end{tabular}

Source: Elaborate by the authors

In comparison to Welch (2007), based on the American market, equity capital is more used in assets financing by the Brazilian market. Welch (2007) had averages of $27 \%, 48 \%$ and $25 \%$, with accounting values, and $23 \%, 42 \%$ and $35 \%$, with market values for FD/TA, NFD/TA and E/TA, respectively.

However, both papers emphasize the importance of non-financial debt in assets financing. Table 4 shows the results achieved for Equations 2 and 3.

The results are similar to those in Tables 2 and 3. First, all coefficients presented the expected sign, as an increase in the E/TA causes a reduction in the FD/TA, as well as statistic relevance.

The regressions with variables on their levels presented an $\mathrm{R}^{2}$ of 0.495 , which meant that $49.5 \%$ of E/TA variation is explained by the FD/TA variations.

However, the purpose is to learn the impact of the non-financial debt on the real leverage ratio, represented herein by one minus the dependent variable.

Therefore, $50.5 \%$ of the cross-sectional heterogeneity of the real leverage is due to the non-financial debt, while most of the variation of the ratio E/TA comes from variations to the non-financial debt.

Upon the execution of regressions with variables in differences, this percentage rises to $66.5 \%$, further increasing the importance of the non-financial debt.By using 
market values, the $\mathrm{R}^{2}$ coefficients of $48.2 \%$ and $40.9 \%$ (Table 5) were achieved, respectively, keeping, thus, the non-financial debt relevance in the explanation to the real leverage ratio $(51.8 \%$ and $59.10 \%$, respectively).

Table 4 - Level and Difference Regressions to Accounting Values

\begin{tabular}{l|l|l|l|l|l}
\hline \multirow{2}{*}{ Period } & \multicolumn{2}{|l|}{ Inclination Coefficient; } & \multicolumn{2}{l}{$\mathrm{R}^{2}$} & \multirow{2}{*}{$\mathrm{N}$} \\
\cline { 2 - 5 } & Level & Difference & Level & Difference & 106 \\
1996 & $-1,110$ & $-0,790$ & 0,526 & 0,367 & 107 \\
1997 & $-1,088$ & $-0,711$ & 0,515 & 0,396 & 103 \\
1998 & $-0,961$ & $-0,380$ & 0,459 & 0,083 & 122 \\
2000 & $-1,078$ & $-0,826$ & 0,487 & 0,447 & 148 \\
2001 & $-0,955$ & $-0,598$ & 0,470 & 0,216 & 148 \\
2002 & $-0,926$ & $-0,849$ & 0,468 & 0,640 & 144 \\
2003 & $-0,937$ & $-0,449$ & 0,494 & 0,186 & 143 \\
2004 & $-0,992$ & $-0,691$ & 0,501 & 0,426 & 155 \\
2005 & $-1,029$ & $-0,295$ & 0,481 & 0,084 & 164 \\
2006 & $-0,994$ & $-0,682$ & 0,423 & 0,305 & 169 \\
2007 & $-1,113$ & $-0,955$ & 0,503 & 0,531 & 92 \\
\hline Avg. & $-1,111$ & $-0,802$ & 0,617 & 0,334 & 133 \\
Standard Error & $-1,024$ & $-0,620$ & 0,495 & 0,335 & \\
Statistic t & 0,021 & 0,096 & & & \\
\hline Source: Elaborat by & $-48,945$ & $-6,470$ & & & \\
\hline
\end{tabular}

Source: Elaborate by the authors

Therefore, more than half of the cross-sectional heterogeneity of the leverage ratio comes from the variations to the ratio NFD/TA, leading to the rejection of hypothesis 1 hereof, stating that most part of the variability in leverage is due to the variability in the Financial debt, and ratifies Welch's (2007) findings, based on the American market.

Table 5 - Level and Difference Regressions to Market Values

\begin{tabular}{|c|c|c|c|c|c|}
\hline \multirow{2}{*}{ Period } & \multicolumn{2}{|c|}{ Inclination Coefficient; } & \multicolumn{2}{|l|}{$R^{2}$} & \multirow{2}{*}{$\mathrm{N}$} \\
\hline & Level & Difference & Level & Difference & \\
\hline 1996 & $-1,039$ & $-0,935$ & 0,480 & 0,404 & 106 \\
\hline 1997 & $-1,124$ & $-0,810$ & 0,525 & 0,418 & 107 \\
\hline 1998 & $-0,827$ & $-0,699$ & 0,412 & 0,367 & 103 \\
\hline 1999 & $-1,087$ & $-0,848$ & 0,481 & 0,492 & 122 \\
\hline 2000 & $-1,044$ & $-0,689$ & 0,443 & 0,240 & 148 \\
\hline 2001 & $-1,001$ & $-0,821$ & 0,415 & 0,486 & 148 \\
\hline 2002 & $-0,907$ & $-0,663$ & 0,374 & 0,303 & 144 \\
\hline 2003 & $-1,117$ & $-0,892$ & 0,483 & 0,425 & 143 \\
\hline 2004 & $-1,239$ & $-0,568$ & 0,477 & 0,160 & 155 \\
\hline 2005 & $-1,223$ & $-1,007$ & 0,442 & 0,420 & 164 \\
\hline 2006 & $-1,415$ & $-1,045$ & 0,541 & 0,482 & 169 \\
\hline 2007 & $-1,426$ & $-1,733$ & 0,709 & 0,708 & 92 \\
\hline Avg. & $-1,121$ & $-0,893$ & 0,482 & 0,409 & 133 \\
\hline Standard Error & 0,053 & 0,087 & & & \\
\hline Statistic t & $-21,334$ & $-10,968$ & & & \\
\hline
\end{tabular}

Source: Elaborate by the authors

In respect to the results achieved in Welch's (2007) research, the author divided the sample in two sub-samples, using as separation point the market value of the 
Standard \& Poor's 500 (S\&P 500) Index: one for large companies, with the assets' market and accounting value 8 times over the value of the S\&P 500 Index(500 companies in total), and other with companies with the assets' market and accounting value 0.2 times over the value of the S\&P 500 Index (3000 companies in total). The intention was to separate the results achieved when using only large companies, from the results including low market and accounting value assets companies.

By using the 3000 companies, Welch (2007) had an $\mathrm{R}^{2}$ coefficient of $49 \%$ and $34 \%$, for the regressions with the variables on level and differences, respectively, using accounting values, which are similar results to those hereof.

However, when analyzing only large companies, the $\mathrm{R}^{2}$ coefficients decrease to $4 \%$ and $29 \%$, with regressions on levels and differences, respectively, using accounting values, and to $10 \%$ and $39 \%$, using market values. These results demonstrate an even higher relevance of non-financial debt.

The same procedure cannot apply herein, due to the restriction of the number of companies traded in the stock exchange and with data available in the Brazilian market.

In order to analyze if the use of different leverage proxies distort the regression results, hypothesis 2 hereof, the model represented by Equation 4 was applied. All variables were normalized with zero average and standard deviation of one, aimed at comparing the economic importance of the estimated coefficients. Then, the estimated coefficient measures the impact of a standard-deviation of the variations to the independent variables on the variations to the dependent variable. All variables are measured to accounting value, except for the market-to-book, which, by definition, includes market value. Finally, the determination coefficients are not comparable, considering that they have different dependent variables, but they are registered.

Table 6 shows the results from regressions with different leverages. All estimate coefficients have the same sign, regardless the leverage used. This is due to the high correlation between the leverage herein.

However, the economic relevance is variable, according to the methodology applied. The assets tangibility and the ratio market-to-book are more important upon the application of TD/TA ratio. The log of assets, in turn, has proven to be more important upon the application of the FD/TA ratio.

As far as the relevance is concerned, there is also variation upon the application of several leverage measures. The log of assets variable was relevant upon the 
application of FD/TA and FD/CI. However, using the variable TD/TA as dependent variable causes the loss of statistic relevance to said variable.

Market-to-book, assets profitability and tangibility variables did not present any changes of relevance, any leverage measure used being relevant. Assets profitability and tangibility were relevant, even when part to the assets is used as dependent variable.

Therefore, profitability is the only variable that is reasonably consistent, in magnitude, sign and significance, with the different measures of leverage, leading to the rejection of hypothesis 2 hereof, stating that the capital structure is sensitive to the measures used to measure the leverage, and to the agreement with Welch (2007). In Welch (2007), the only variable that is reasonably consistent is also profitability.

Finally, despite not being the purpose hereof, we found that all variables, except for market-to-book, agree with the theory, i.e.:

- Profitability: negative relation, as per pecking order theory;

- Size: positive relation, as per bankruptcy costs theory;

- Assets tangibility: positive relation, according to the agency theory.

As to the market-to-book variable, a positive relation was found, against the market timing theory, estimating a negative relation between such variable and debt.

Thus, future empirical research should be developed to investigate such theory further.

Table 6 - Regressions with Different Leverage Proxies

\begin{tabular}{|c|c|c|c|c|c|c|}
\hline \multirow{2}{*}{$\begin{array}{l}\text { Dependent } \\
\text { Variables }\end{array}$} & \multicolumn{4}{|c|}{ Independent Variables } & \multirow{2}{*}{$\mathrm{N}$} & \multirow{2}{*}{$\mathrm{R}^{2}$} \\
\hline & LogAt & MB & NP/TA & Tang & & \\
\hline $\begin{array}{l}\text { FD/TA } \\
\text { Avg. } \\
\text { Standard Error } \\
\text { Statistic t }\end{array}$ & $\begin{array}{l}0,150 \\
0,014 \\
10,390\end{array}$ & $\begin{array}{l}0,119 \\
0,050 \\
2,369\end{array}$ & $\begin{array}{l}-0,273 \\
0,027 \\
-10,271\end{array}$ & $\begin{array}{l}0,254 \\
0,077 \\
11,503\end{array}$ & 133 & 0,20 \\
\hline $\begin{array}{l}\text { FD/CI } \\
\text { Avg. } \\
\text { Standard Error } \\
\text { Statistic t }\end{array}$ & $\begin{array}{l}0,110 \\
0,016 \\
7,083 \\
\end{array}$ & $\begin{array}{l}0,142 \\
0,052 \\
2,753 \\
\end{array}$ & $\begin{array}{l}-0,220 \\
0,053 \\
-4,114\end{array}$ & $\begin{array}{l}0,281 \\
0,024 \\
11,475 \\
\end{array}$ & 133 & 0,21 \\
\hline $\begin{array}{l}\text { TD/TA } \\
\text { Avg. } \\
\text { Standard Error } \\
\text { Statistic t }\end{array}$ & $\begin{array}{c}0,001 \\
0,026 \\
-0,05\end{array}$ & $\begin{array}{l}0,189 \\
0,029 \\
6,455\end{array}$ & $\begin{array}{l}-0,288 \\
0,024 \\
-12,041\end{array}$ & $\begin{array}{l}0,387 \\
0,025 \\
15,347\end{array}$ & 133 & 0,28 \\
\hline $\begin{array}{l}\text { 1/TA } \\
\text { Avg. } \\
\text { Standard Error } \\
\text { Statistic t }\end{array}$ & $\begin{array}{l}-0,561 \\
0,122 \\
-4,592\end{array}$ & $\begin{array}{l}0,060 \\
0,041 \\
1,448\end{array}$ & $\begin{array}{l}-0,087 \\
0,025 \\
-3,428\end{array}$ & $\begin{array}{l}0,078 \\
0,024 \\
3,320\end{array}$ & 133 & 0,53 \\
\hline
\end{tabular}

Source: Elaborate by the authors

\section{CONCLUSION}

This paper aimed at checking the capital structure sensibility to leverage measures. It intended, as well, to check if most part of the leverage variability is due to the variability of the Financial Debt. Based on Tables 4 and 5, more than half of the 
cross-sectional heterogeneity of the leverage ratio comes from the variations to the ratio NFD/TA, leading to the rejection of hypothesis 4 hereof, stating that most part of the leverage variability is due to the variability in the Financial Debt, and ratifies Welch (2007) findings, based on the American market.

In respect to the sensibility to the leverage measures, according to Table 6 , the variable profitability was the only one that is reasonably consistent, in magnitude, sign and significance, with the different leverage measures used, leading to the rejection of hypothesis 2 hereof, stating that the capital structure is sensible to the leverage measures, agreeing with Welch (2007).

The conclusion from the results hereof is that the opposite to the Financial debt divided by Total Assets ratio is not necessarily equal to the Equity divided by Total Assets ratio, due to the presence of Non-Financial Debt in the assets financing, the percentage of which is relevant to this research. Thus, future research should not use the Financial Debt / Total Assets ratio as leverage measure, but the Total Debts / Total Assets or Financial Debt / Invested Capital ratio.As to the results existing in the literature, one cannot state that they are sensible to the leverage definitions. However, the studies using the Financial Debt / Total Assets as leverage measure may require a new analysis and confirmation. Finally, the interferences made in this paper can only extend to the population from which the samples were taken, and the results cannot be generalized to all non-financial companies listed in Bovespa.

\section{REFERENCE}

BAKER, M.; WURGLER, J. Market timing and capital structures. Journal of Finance, v. 57, n.1, p. 1-30, 2002.

BRIGHAM, E. F.; HOUSTON, J. F. Fundamentos da moderna administração financeira. Rio de Janeiro: Campus, 1999.

BRITO, R. D.; LIMA, M.R. A escolha da estrutura de capital sob fraca garantia legal: O Caso do Brasil. Revista Brasileira de Economia, v.59, n.2, p. 177-208, 2005.

Da SILVA, J. C. G.; BRITO, R. D. Testando as previsões de trade-off e pecking order sobre dividendos e dívida para o brasil. . In: SBFIN, 3, 2003. São Paulo. Anais... São Paulo, 2003.

DEANGELO, H.; MASULIS, R. W. Optimal capital structure under corporate and personal taxation. Journal of Financial Economics, v. 8, n. 1, p. 3-29, 1980.

FAMA, E. F.; FRENCH, K.R.Testing trade-off and pecking order predictions about dividends and debt. The Review of Financial Studies, v.15, n.1, 2002. 
FAMA, E. F.; MACBETH, J. D. Risk, return and equilibrium: empirical tests. The Journal of Political Economy, v.18, n.3, p. 607-636, 1973.

FAMÁ, R.; BARROS, L. A. B. de C.; SILVEIRA, A. Di M.. A Estrutura de capital é relevante? Novas evidências a partir de dados norte-americanos e latino-americanos. Caderno de pesquisa em administração, São Paulo, v. 8, n. 2, abr./jun. 2001.

FLANNERY, M. J. ; RANGAN, K. P. Partial adjustment toward target capital structures. Journal of Financial Economics, v. 79, n.3, p.469-506, 2006.

GRAHAM, J. R.; HARVEY, C. R. The theory and practice of corporate finance: evidence from the field. Journal of Financial Economics, v.60, p. 187-243, 2001.

HARRIS, M.; RAVIV, A. The theory of capital structure. The journal of finance, v. 46, p. 297-355, 1991.

JENSEN, M. C.; MECKLING, W. H. Theory of the firm: managerial behavior, agency cost and ownership structure. Journal of Financial Economics, v.3, p. 305-360, 1976.

KJELLMAN, A.; HANSÉN, S. Determinants of capital structure: theory vs. practice. Scand. J. Magmt, v. 11, n. 2, p. 91-102, 1995.

MARTINS, G. Manual para elaboração de monografias e dissertações. 3 ed. São Paulo: Atlas, 2002.

MODIGLIANI, F.; MILLER, M. H. The cost of capital, corporate finance and the theory of investment. The American Economic Review, v.48, p. 261-297, 1958.

MYERS, S. C. The Capital structure puzzle. The Journal of Finance, v. 39, p.575-592, 1984.

MYERS, S. C.; MAJLUF, N. S. Corporate financing and investment decisions when firms have information that investors do not have. Journal of Financial Economics, v.13, p. 187-221, 1984.

ROSS, S. A.; WESTERFIELD, R. W.; JAFFE, J. F. Corporate Finance. New York: McGraw-Hill, 2001.

SCOTT, L. D. F. Evidence on the importance of financial structure. Finance Management, p. 45-50, 1972.

SHYAM-SUNDER, L.; MYERS, S. C. Testing static tradeoff against pecking order models of capital structure. Journal of Financial Economics, v.51, .2, p. 219-244, 1999.

WELCH, I. Capital structure and stock returns. Journal of Political Economy, v. 112, n. 1, p. 106-131, 2004.

. Common flaws in empirical capital structure research. Working paper, Brown University, National Bureau of Economic Research (NBER), Paper Available at SSRN: http://ssrn.com/abstract=931675, 2007. 